\title{
TEKNIK PEMBELAJARAN KOLABORATIF UNTUK MEMANDIRIKAN CALON JAMAAH HAJI PADA KELOMPOK BIMBINGAN HAJI MASJID ISTIQAMAH UNGGARAN
}

\author{
Muh Saerozi \\ Sekolab Tinggi Agama Islam Negeri (STAIN) Salatiga \\ Saerozi2010@yaboo.com
}

\begin{abstract}
This quantitative research is intended as part of alternative solution for the Hajj at Masjid Istiqomah Ungaran in 2013. The research is focused on the technique on how to make the Hajj tobe self-reliance. Observation and interview are the technique on collecting the data through inductive approach. The finding shows (1) being self-reliance for the Hajj on religious activities and travel are not individual but collective; (2) improving one self-reliance not only require one but also collaborative teaching technique. (3)this collaborative technique will be effective when there is a support from the participant with different educational background and the organizer who knows the participant as an adult.
\end{abstract}

Keyword: Guidance, Manasik Haji, Teaching Technique, self-reliance, Adult.

\begin{abstract}
Abstrak
Penelitian kualitatif ini dibarapkan menjadi alternatif solusi atas problem kemandirian calon jamaah haji. Subyek penelitian adalab Kelompok Bimbingan Manasik Haji Mesjid Istiqomab Ungaran tabun 2013. Penelitian difokuskan pada teknik pembelajaran untuk memandirikan calon jamaab haji. Teknik pengumpulan data yang digunakan adalab observasi dan wawancara. Analisis data menggunakan pendekatan induktif. Dari proses tersebut diketabui babwa (1) kemandirian calon haji dalam aspek ibadab dan perjalanan tidak selalu bersifat individual, tetapi juga bersifat kolektif.(2) Pengembangan satu kompetensi kemandirian tidak cukup hanya dengan satu teknik pembelajaran, tetapi diperlukan kolaborasi. (3) Teknik pembelajaran kolaboratif tersebut bisa efektif, sebab didukung
\end{abstract}


oleb peserta didikyang beragam latar belakang pendidikan, profesi, dan kecakapan keagamaan. Didukung pula oleb penyelenggara yang memahami kondisi peserta didik sebagai orang dewasa.

Kata kunci: Bimbingan, Manasik Haji, Teknik pembelajaran, Kemandirian, Orang dewasa.

\section{Pendahuluan}

Bimbingan manasik haji merupakan amanat Undang-Undang Republik Indonesia Nomor 13 tahun 2008. Kegiatan bimbingan merupakan bagian dari unsur pembinaan terhadap jamaah haji. Penyelenggara bimbingan manasik dalam praktiknya adalah Kantor Urusan Agama (KUA). Namun mayoritas bimbingan manasik KUA kurang memuaskan peserta (Imam Syaukani (Ed.), 2009:52-53). Bimbingan manasik juga belum berhasil memandirikan jamaah haji dalam ibadah maupun proses perjalanannya. Di sisi lain, kemandirian jamaah sangat urgen untuk kelancaran, kenyamanan, dan kekhusukan ibadah (Slamet Riyanto dalam Budiman (ed.), 2010:181). Kemandirian jamaah memperoleh perhatian khusus dalam pasal 18 Keputusan Menteri Agama Nomor 396 Tahun 2003.Direktorat Haji pada tahun 2010 juga menjadikan kemandirian jamaah sebagai arah pembinaan haji (Slamet Riyanto, dalam Budiman (ed.), 2010:97).

Atas dasar problem kemandirian tersebut, maka Kementerian Agama mendorong KUA agar melibatkan Ormas Islam, Pondok Pesantren, Ikatan Persaudaraan Haji Indonesia (IPHI), dan ulama setempat. Masyarakat secara perorangan atau kelompok juga diberi peluang untuk menyelenggarakan bimbingan manasik haji (Slamet Riyanto, dalam Budiman (ed.), 2010:97, 181).

Yayasan Istiqomah sebagai lembaga swasta di Ungaran merespon peluang tersebut. Jawaban strategis yang dilakukan adalah menyelenggarakan bimbingan manasik haji bekerjasama dengan IPHI Kecamatan Ungaran. Penyelenggaraan bimbingan manasik di Mesjid Istiqomah ini menarik untuk diteliti. Ada beberapa faktor yang dapat disebutkan di sini. Pertama, usia kelompok bimbingan termasuk "tua" di Kab. Semarang. Berdiri sejak tahun 2003. Kedua, 
jumlah peserta bimbingan stabil setiap tahun.Antara 100-150 orang. Ketiga, peserta dan tutor memiliki latar belakang paham keislaman yang beragam. Keempat, peserta memiliki tingkat pendidikan dan profesi yang beragam pula. Kelima, peserta memiliki kemampuan 'Arabiyah yang beragam. Ada yang sudah mahir, tetapi ada yang tidak bisa sama sekali.

Selain faktor-faktor tersebut, ada faktor keenam, jamaah dinilai mampu mandiri dan toleran terhadap perbedaan pendapat. Penilaian semacam ini sudah umum didengar dari para alumni bimbingan, para petugas haji, dan beberapa pejabat Kementerian Agama serta Pemerintah Daerah.

Pertanyaan pokok yang ingin diketahui dari penelitian ini adalah bagaimanakah sifat kemandirian peserta bimbingan? teknik pembelajaran apa saja yang diterapkan untuk kemandirian calon haji? Bagaimana teknik-teknik tersebut dipraktikkan dalam kegiatan pembelajarannya? Untuk menjawab pertanyaan-pertanyaan tersebut tentu tidak bisa dilepaskan dari ulasan sekilas tentang tutor, materi bimbingan manasik, karakteristik peserta, dan metode-metode pembelajaran. Faktor-faktor tersebut saling terkait (Abdul Majid, 2013:232).

\section{Bimbingan dan Kompetensi Kemandirian}

Masyarakat luas meskipun belum tahu persis arti bimbingan, tetapi mereka sudah familiar dengan istilah "bimbingan manasik haji" (Dirjen penyelenggaraan Haji dan Umrah, 2001:11). Istilah bimbingan berasal dari kata "bimbing" yang berarti juga pimpin, asuh, tuntun (Tim redaksi Kamus Besar bahasa Indonesia, 2007:152). Bimbingan cenderung pada usaha sadar dan terencana untuk menuntun orang supaya dapat bersikap, berpengatahuan, dan berketerampilan sesuai pedoman tertentu (Uyoh Sa'dullah, 2011:8).

Untuk mewujudkan tujuan itu, maka sekurang-kurangnya ada tiga kompetensi yang perlu dimiliki calon haji.yaitu:

1. Sikap, pengetahuan dan keterampilan tentang keimigrasian pergi haji. Ada peraturan perundang-undangan dan urgensi dokumendokumen, seperti prosedur-prosedur, dokumen paspor, vaksin meningitis, gelang haji, dan alat tukar. 
2. Sikap, pengetahuan, dan keterampilan tentang manajemen perjalanan ibadah haji. Dalam manajemen perjalanan itu menyangkut pula aspek perlengkapan material, perlengkapan finansial, dan prosedur-prosedur penerbangan. Manajemen perjalanan juga akan berpengaruh pada keabsahan dan keutamaan ibadah.

3. Sikap, pengetahuan, dan keterampilan tentang prosesi ibadah haji. Ada syarat, wajib, rukun, dan sunnah haji. Ada aspek hati, ucapan, dan perbuatan ibadah. Ada aspek fiqih dan tasawuf dalam ibadah.

4. Sikap, pengetahuan, dan keterampilan tentang kesehatan. Ada aspek aspek fisik dalam diri jamaah haji, tetapi juga psikis. Kesehatan ini terkait erat dengan keutamaan ibadah.

5. Sikap, pengetahuan, dan keterampilan tentang "setia kawan". Kompetensi ini penting untuk setiap calon haji supaya mampu rukun dan kompak. Supaya mereka mampu pula untuk menjaga diri dari jidal dan fusuk.

6. Sikap, pengetahuan, dan keterampilan tentang budaya dan iklim negara tujuan. Kompetensi ini berguna untuk menumbuhkan sikap dan perilaku yang tepat selama berada di negara tujuan.

\section{Teknik Pembelajaran}

\section{Peserta Didik Dewasa}

Bimbingan manasik haji dalam perspektif Undang-undang termasuk dalam kategori pendidikan informal (Tim Redaksi Wacana Intelektual, 2006:56, 62). Mereka yang hadir mengikuti bimbingan disebut sebagai peserta didik pendidikan informal. (Tim Redaksi Sinar Grafika. 2013:6). Tidak ada batasan usia untuk menjadi peserta didik jalur informal, sehingga calon haji dengan usia yang beragam bisa masuk di dalamnya. Ragam usia jamaah haji bisa dibaca dari data Kementerian Agama tahun 2010. Jumlah calon haji 189.358 orang.Mereka yang berusia antara 1 sampai 40 tahun berjumlah 35.795 orang (18, 9\%).Selebihnya berusia antara 41 sampai dengan 90 tahun ke atas (Direktorat Jenderal Penyelenggraan Haji dan Umrah, 2010:49). 
Usia 40-90 tersebut menurut Hj. Samsu Numiyati Mar'at (2010:234-244) dimasukkan dalam dua kategori, yaitu kategori pertengahan masa dewasa (40 tahun sampai 65 tahun) dan masa dewasa lanjut (65 tahun sampai wafat). Dalam perspektif psikologi, ada perubahan-perubahan spesifik dalam usia tersebut, seperti fisik, sensori, kognitif, memori, psikososial.

Belajar bagi orang dewasa lebih mengarah pada pemantapan kemampuan dan keterampilan dasar yang pernah diperoleh sejak masa kanak-kanak. Ini berbeda dengan belajar masa anak-anak dan remaja yang cenderung untuk mengoleksi informasi (Anisah Basleman dan Syansu Mappa, 2011:16). Menurut pannen, dalam H. Suprijanto (2007:11) pendidikan bagi orang dewasa berlangsung dalam bentuk pengarahan diri sendiri untuk memecahkan masalah, sedangkan pendidikan untuk anak-anak berlangsung dalam bentuk identifikasi dan peniruan.Menyimak pada perbedaan psikologis tersebut, maka pendekatan pembelajaran yang tepat untuk mereka juga berbeda. Orang dewasa menggunakan pendekatan andragogi, sedangkan untuk anak-anak menggunakan pendekatan pedagogi.

\section{Macam-Macam Teknik Pembelajaran}

Teknik pembelajaran berbeda dengan metode pembelajaran dan pendekatan pembelajaran. Pendekatan pembelajaran adalah "cara yang dilakukan untuk menyelesaikan persoalan pembelajaran secara menyeluruh" (Suwarna, dkk., 2005:101). Adapun teknik pembelajaran adalah siasat yang dilakukan oleh guru dalam mengimplementasikan metode pembelajaran. (2013:233).

berikut:

Di antara teknik pembelajaran tersebut adalah sebagai

a. Teknik bertanya, yaitu siasat yang tepat bagi pendidik untuk mengajukan petanyaan kepada peserta didik. Pertanyaan harus efektif untuk suatu tujuan pembelajaran.

b. Teknik memberi penguatan (reinforcement), yaitu siasat yang tepat bagi pendidik untuk memberikan penguatan kepada peserta didik supaya perhatian mereka bertambah intensif.

c. Teknik menjelaskan, yaitu siasat yang tepat bagi pendidik untuk merefleksi segala informasi yang dimilikinya kepada peserta 
didik sesuai dengan kehidupan mereka sehari-hari.

d. Teknik membuka dan menututp pelajaran, yaitu siasat yang tepat bagi pendidik untuk memulai pelajaran dan menutupnya.

e. Teknik melakukan variasi, yaitu siasat yang tepat bagi pendidik untuk mengurangi kebosanan peserta didik dalam proses pembelajaran. Penerapan teknik variasi pembelajaran yang tepat membawa peserta didik tetap tekun dan partisipatif (Abdul Majid, 2013:233-240).

\section{Metodologi}

Fokus penelitian ini adalah teknik pembelajaran untuk memandirikan calon jamaah haji. Peneliti mengaplikasikan pendekatan yang dianggap cocok untuk fokus tersebut, yaitu kualitatif. Lokasi penelitian di Kelompok Bimbingan manasik haji di Mesjid Istiqomah Ungaran. Subyek penelitian adalah person-person yang terlibat dalam bimbingan manasik haji. Dalam laporan penelitian ini, para responden hanya ditulis inisialnya saja. Pengumpulan data dilakukan dengan teknik observasi dan wawancara. Observasi dilakukan pada fase pertama saat bimbingan berlangsung. Observasi difokuskan pada proses bimbingan khususnya yang terkait dengan penerapan teknik pembelajaran. Analisis data penelitian ini menggunakan model induksi.

\section{Analisis}

\section{Penyelenggaraan Bimbingan Manasik}

a. Motivasi Penyelenggaraan dan Implikasi Praktis

Bimbingan manasik haji diselenggarakan di aula Mesjid Besar Istiqomah Jalan Diponegoro nomor 36 Ungaran. Lokasi mesjid tergolong strategis, sebab berada di jalan utama dari kota Semarang menuju Solo dan Yogyakarta. Bimbingan terselenggara atas kerjasama Yayasan Mesjid Istiqomah dengan IPHI Kecamatan Ungaran sejak tahun 2003.

Ide awal penyelenggeraan bimbingan manasik itu, menurut Hsn ( \pm 51 tahun) selaku sekretaris yayasan, selain untuk membantu pemerintah dalam program pembinaan haji, juga sebagai usaha 
memakmurkan mesjid dan syiar Islam. Penuturan Hsnitu dibenarkan oleh Jrs ( \pm 65 tahun) sebagai mantan ketua IPHI saat itu (wawancara tanggal 13 Maret 2013).

Senada dengan penuturan Hsn, dan Jrs tersebut, Rwd $( \pm 66$ tahun) selaku imam Mesjid Istiqomah menegaskan bahwa kegiatan bimbingan ini sebagai salah satu ekspresi dari cita-cita dan semangat para pendiri mesjid kala itu (1978) (wawancara tanggal 15 Maret 2013).

Semangat pendiri yayasan dapat disimak dari pernyataan Syn ( \pm 86 tahun). Ia mennyampaikan "kisah heroiknya" ketika masa awal pendirian mesjid. Syn sebagai pejabat saat itu merasakan posisinya yang sulit, sebab tidak semua atasannya setuju dengan prinsip dan langkahnya (Wawancara tanggal 8 Oktober 2013). Saat itu memang jaman Orde Baru.Hubungan antara Islam dan negara berada diujung masa antagonistik (1966-1982). Aktivis mesjid bisa dicurigai sebagai muslim radikal (Abdul Aziz Thaba, 1966:240-152). Apalagi mesjid itu berdiri di depan gereja yang sudah berdiri lebih dulu (tahun 1933) (Rm. Al. Budyapranata, dkk.,1997:8).

Petuah para pendiri yayasan itu menjadi bagian dari motivasi pengurus Yayasan untuk mengelola bimbingan manasik haji yang berkualitas. Ath selaku ketua yayasan menuturkan bahwa untuk mengejar kualitas output, maka frekuansi bimbingan harus lebih banyak dibandingkan dengan bimbingan di KUA. Fasilitas pembelajaran harus lebih lengkap. Tutor juga harus konsisten dan profesional.

Oleh karena itu, Bimbingan di sini dilaksanakan 20 kali terhitung mulai bulan Februari sampai sepekan menjelang bulan Ramadhan.Pembelajaran dilaksanakan pada setiap hari Ahad sejak pukul 13.00 sampai dengan pukul 16.00 (wawancara tanggal 4 April 2013).

\section{b. Kompetensi Pengelola Bimbingan}

Untuk mewujudkan bimbingan manasik yang berkualitas, maka pengelolaan dilakukan secara kolegial. Ketua, sekretaris, dan bendahara dipegang langsung oleh pengurus harian yayasan. Dalam kelompok bimbingan itu ada pula tutor-tutor dari pengurus yayasan, 
tetapi ada pula yang dari luar yayasan. Tutor bimbingan tercatat nama-nama yang sudah banyak dikenal orang di Ungaran dan sekitarnya.

Dilihat dari aspek pendidikan, hanya ada dua tutor yang dididik secara formal untuk "kompetensi andragogik". Sedangkan yang lainnya didik di fakultas kedokteran, hukum, perkebunan, hukum Islam, peternakan, dan komunikasi. Dari aspek pendidikan formal, mereka memang tidak mendapatkan ilmu "andragogik" itu.

Peneliti dalam proses observasi juga menemukan fakta tentang keluwesan tutor. Misalnya, Rml yang sehari-hari berposisi sebagai pejabat eselon 2 di Pemkab Semarang memilih tugas di "front office" aula untuk melayani peserta untuk mengisi daftar hadir. Hsn yang sehari-hari sebagai kepala bagian di Pemkab Semarang mempraktikkan pengobatan secara langsung kepada peserta. Arf yang sehari-hari sebagai pengusaha turut menyiapkan sound system di aula.

Ny. Aid sebagai peserta menuturkan kepada peneliti di akhir Juni 2013 bahwa perilaku panitia dan tutor yang luwes itu telah membuat peserta nyaman. Mereka menjadi akrab dan semangat, sebab diperlakukan hormat layaknya orang dewasa.

c. Komposisi Peserta

Peserta bimbingan pada tahun 2013 tercatat 123 orang. Peserta laki-laki berjumlah 73 orang (59,35\%). Peserta perempuan 50 orang (40, 65\%). Para peserta ternyata tidak menuliskan identitas mereka secara lengkap, sehingga peneliti kesulitan menemukan identitas lengkapnya.Kesulitan peneliti agak teratasi berkat wawancara dan pengamatan pada saat proses bimbingan berlangsung. Pemetaan peserta secara umum dapat diketahui, seperti aspek usia, pendidikan, profesi, paham keagamaan, dan kesehatannya.

Menurut informasi Ltf (petugas "front office" mesjid), mayoritas peserta bimbingan tahun 2013 berusia 40-82 tahun. Usia tersebut merepresentasikan usia jamaah haji secara nasional. Misalnya, Smn sebagai salah seorang peserta lahir tanggal 21 januari 1932. (wawancara dengan seorang putranya pada Desember 2013). Dalam bimbingan ini tidak dijumpai peserta berusia antara 1-25 tahun. 
Latar belakang budaya peserta juga bervariasi. Ada yang berasal dari suku Bali, seperti Ny. Ketut I. Ada yang Sunda seperti Azz, dan Betawi seperti Ers. Namun, mayoritas dari mereka berasal dari Jawa Tengah. Ada Jawa Tengah Pegunungan, tetapi ada pula Jawa Tengah pesisiran.

Dilihat dari aspek pendidikan, peserta bimbingan tahun 2013 ada 1 orang profesor sejarah dari Perguruan Tinggi Umum (Stj), ada 1 doktor (Sbn), 2 Magister (Rmj dan Srn), dan beberapa orang sarjana dari beberapa disiplin ilmu. Meskipun begitu, mayoritas hanya lulus SLTA dan SMP, dan bahkan hanya ada yang tamat SD, seperti Rkm ( \pm 47 tahun).

Salah seorang panitia bernama Rml menuturkan tentang profesi peserta secara umum. Ada peserta yang berprofesi sebagai dosen seperti Stj, Sbn, dan Rmj. Ada pula yang masih aktif sebagai PNS, seperti Mlt. Ada yang masih aktif sebagai polisi seperti Hsn. Ada yang sudah pensiun agak lama seperti Nrt, Spr, dan Rjr. Ada 1 orang pilot, yaitu Yhn. Ada beberapa pedagang, seperti Srh, petani seperti Srd. Ada pula pengusaha seperti Mhr ( \pm 45 tahun).

Paham keagamaan peserta ternyata juga bervariasi. Ada peserta yang berafiliasi pada paham keagamaan Muhammadiyah, seperti Znd, Rmj, Ny. ttn, dan Ny. Spt. Mereka mengikuti bimbingan di Mesjid Istiqomah karena ada tutor yang berafiliasi keagamaan sama. Ada pula yang berafiliasi pada Nahdlatul Ulama, seperti Srd dari Kecamatan Ungaran, Mkb dari Langensari, Rhf dari Kalirejo, serta stn.

Ada peserta yang diindikasikan pernah setia pada aliran "kejawen", seperti Skm. Ada pula peserta yang tidak tahu kemana afiliasi keagamannya, seperti Ykc, Srt, Yhn, Wnt, Js, dan Sdw. Peserta seperti yang disebut terakhir ini merasa tidak punya kepentingan dengan organisasi atau paham keagamaan tertentu.

Kesehatan peserta bimbingan juga bervariasi. Ada yang segar bugar seperti Kmn, Ers, Azz, Hsn, Hru, En, Mhr, dan Umy, tetapi ada pula yang menderita sakit, seperti Mhm dan Mht. Jumlah peserta yang sehat lebih banyak dibanding yang sakit.Peserta juga bervariasi dari aspek kecakapan membaca dan menulis Arab. Misalnya, Sdr tergolong lancar membaca tulisan Arab. Ia berani tampil ke depan 
memimpin kawan-kawannya berlatih doa-doa. Peserta lain yang seperti Sdr ini hanya ada beberapa, seperti Mhr, Znd, dan Ny. Ulf. Mayoritas peserta belum bisa membaca tulisan Arab secara mahir seperti Sdr itu. Bahkan ada pula peserta yang sama sekali belum bisa membaca tulisan Arab. Mereka yang kondisinya seperti itu menggantungkan diri pada tulisan Arab latin sebagai transliterasinya.

d. Spesifikasi Materi

Materi bimbingan manasik di Mesjid Istiqomah secara umum sama dengan manasik di tempat lain. Hsn selaku koordinator penyusun kurikulum bimbingan juga merujuk pada buku-buku terbitan Kementerian Agama. Ketika peneliti berkunjung ke rumah Hsn di bulan April 2013, buku-buku rujukan tersebut misalnya, Regulasi Penyelenggaraan Haji dan Taklimatul Haji, Desain pola penyuluban dan bimbingan jemaab Haji, Panduan perjalanan Haji, Hikmah ibadah Haji, dan lain-lain.

Materi bimbingan disusun ringkas karena mempertimbangkan pada kondisi variatif peserta dari aspek usia dan kecakapannya. Tuntunan doa-doa ibadah yang panjang-panjang seperti dalam buku terbitan Kementerian Agama diringkas oleh tim. Doa-doa yang ringkas tersebut diterbitkan untuk kalangan sendiri dengan judul "Kumpulan Doa Haji dan Umrah".

Bentuk ringkas buku susunan panitia itu dapat dilihat misalnya pada bagian doa tawaf. Buku susunan panitia hanya menulis satu rangkaian doa untuk semua putaran. Berikut ini adalah contoh doa tawaf putaran ke empat yang diringkas itu.

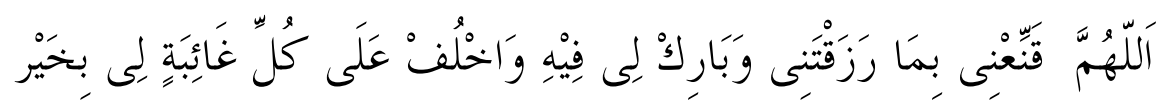

Allaahumma qonni'nii bimaa rozaqtannii wa baariklii fiihi wakhluf 'alaiya kulli ghooibatin lii bikhaiir.

Artinya:

Ya Allah cukupkanlah rezeki yang Engkau rezekikan kepadaku, dan berilah kepadaku keberkahannya, serta gantilah segala yang hilang dariku dengan yang lebih baik. 
Selain buku kumpulan doa, panitia juga memberikan buku saku perjalanan. Isi buku ini bukan berbentuk deskripsi, tetapi tabel-tabel tentang perkiraan jadwal perjalanan.Jamaah selain menerima buku juga menerima materi pelatihan kesehatan mandiri. Pelatihan itu menggunakan pendekatan Hipno terapi dan Sef. Pelatihan pengobatan kesehatan tersebut ditangani langsung oleh Hsn. Khalayak Ungaran dan sekitarnya sudah tahu bahwa Hsn selain ahli agama juga mahir dalam teknik pengobatan ini.

\section{Testimoni Kemandirian}

a. Kemandirian Ibadah

Kemandirian dan sikap percaya diri hampir tidak dapat dipisahkan dalam diri calon jamaah haji. Ada peristiwa yang mendukung pernyataan itu. Dikisahkan oleh Rfi (40) (calon jamaah haji yang gagal berangkat lantaran pemotongan kuota tahun 2013). Saat ayah dan ibunya berangkat ke Embarkasi Solo pada tanggal 28 september 2013, ia juga berangkat mengantar mereka. Rombongan jamaah diberangkatkan dari Ungaran jam 14.15. Sepanjang jalan terjadi kemacetan, sehingga jamaah sampai di embarkasi Solo menjelang magrib (jam 17. 45)

Ketika jamaah haji sampai di aula embarkasi, tiba-tiba ada hampir dua ratusan orang laki-laki dan perempuan bergegas pergi menuju mesjid di komplek itu. Sedangkan jamaah yang lain tetap duduk di tempat. Melihat kejadian itu, Rfi pun berusaha mencari tahu tujuan mereka ke mesjid. Ternyata mereka melaksanakan salat asar. Ketika Rfi bertanya, "Mengapa salat asarnya tidak dijamak taqdim di rumah?". Mereka menjawab bahwa Pak Kyai menyarankan agar mereka melaksanakan salat asar di embarkasi saja.

Setelah Rfi mengamati identitas jamaah, akhirnya diketahui bahwa jamaaah haji yang salat asar di embarkasi tadi ternyata bukan dari bimbingan manasik di Mesjid Istiqomah. Mereka yang mengikuti bimbingan di Mesjid Istiqomah sudah melaksanakan salat asar dengan cara jamak taqdim di rumah. Bahkan salat magrib juga dijama' ta'khir di waktu isya'. Jamaah haji yang melakukan salat dengan cara jama' itu didorong oleh dua faktor. Pertama, mengikuti "fatwa' dari tutor bimbingan. Kedua, menggunakan pertimbangan rasional dalam mengikuti "fatwa". 
Unsur rasional itu tampak dalam diri jamaah ketika mempertimbangkan antara waktu yang tersedia, jarak tempuh, kondisi jalan, dan arus lalu lintas. Mereka telah diajak memahami semua faktor itu, sehingga bisa mantap mengambil keputusan. Mereka tidak mengubah prinsip meskipun ada kawan dari bimbingan lain yang bersikukuh melakukan salat asar di embarkasi. Mereka juga tidak mencela atau melarang kawan dari bimbingan lain yang salat asarnya sudah mepet magrib itu.

Peristiwa yang dikisahkan Rfi tersebut bisa dikategorikan sebagai bentuk kemandirian dalam beribadah. Ia mengerti alasan suatu ibadah dan melakukannya dengan hati yang mantap. Ada lagi penuturan dari Ny. Sdw dan Ny. Srn. Kira-kira delapan hari sebelum waktu wukuf tiba, mereka menyaksikan kawan-kawan satu kloter risau, sebab terdengar kabar bahwa jarak antara kemah di Mina dan lokasi jamarat kira-kira tujuh kilometer. Sebagian jamaah sudah memutuskan untuk tanazul (memisahkan diri dari kloter). Mereka tergiur tawaran oknum tertentu yang berjanji akan mencarikan tempat istirahat yang nyaman dan dekat dengan jamarat.

Sebagian jamaah lagi memutuskan untuk berangkat dari maktab Mekah, karena jaraknya hanya kira-kira 3 kilometer. Mereka berencana setelah melempar jamarat tanggal 10 Dzulhijjah langsung ke Mekah untuk tawaf ifadlah. Mereka akan kembali ke sekitar Jamarat sebelum magrib tiba. Rencana itu akan mereka lakukan pula pada tanggal 11, 12, dan 13 Dzulhijjah. Sebagian lagi adalah jamaah dari bimbingan di Mesjid Istiqomah. Musyawarah di antara mereka memutuskan tidak mengikuti keputusan dua kelompok tadi. Mereka menempuh opsi ketiga, yaitu tetap berangkat dari Kemah di Mina meskipun jaraknya dikabarkan cukup jauh dengan jamarat.

Opsi ketiga ini tidak didasarkan atas pertimbangan keabsahan ibadah, tetapi resiko dari aspek peraturan dan efek samping psikologis. Tanazul dipahami identik dengan penyimpangan terhadap aturan. Berangkat dari Mekah untuk melempar jamarat dipahami kurang memuaskan batin. Bagi mereka yang memilih opsi ketiga ini, perjalanan yang agak jauh dari kemah ke jamarat justru bisa menjadi kenangan indah ketika pulang. Opsi ketiga ini dapat dikategorikan sebagai kemandirian kolektif, sebab di dalamnya ada unsur 
tekad kuat dan taat asas. Dari aspek ibadah terjamin keabsahannya. Dari aspek psikologis terasa menenteramkan hati mereka. Tim Petugas Haji pun mendukung terhadap opsi ketiga itu.

Akhirnya, menurut penuturan Nyt, jamaah yang semula cenderung pada opsi pertama dan kedua berubah mengikuti keputusan opsi ketiga. Berangkat dan pulang dari kemah Mina. Ternyata pula, jarak yang diperkirakan 7 kilometer hanya kira-kira 3 kilometer. Mhm yang sakit stroke dan Mht yang menderita vertigo pun bisa melempar jamarat dengan jasa kursi roda.

b. Kemandirian dalam perjalanan

Panitia bimbingan manasik Istiqomah tidak menugaskan unsur panitia untuk mendampingi jamaah ke Arab Saudi. Keputusan ini berbeda dengan beberapa panitia bimbingan di tempat lain. Ada saja orang yang memberi gambaran sulit dalam perjalanan haji nanti, sebab Mesjidil haram sedang dalam proses renovasi. Mendengar pertimbangan itu, Ath selaku ketua panitia hanya menjawab datar bahwa di setiap kloter sudah ada petugas yang terlatih.

Jawaban Ath tersebut terkesan klise, tetapi sesungguhnya memiliki maksud yang sangat mendasar. Ath yang mengikuti hampir setiap sesi pembelajaran memahami sungguh-sungguh karakter jamaahnya. Ia juga memahami perkembangan sikap, pengetahuan, dan keterampilan mereka. Ath seolah-olah ingin menyatakan bahwa sikap, pengetahuan, dan keterampilan jamaah tentang manajemen perjalanan dan ibadah sudah cukup.Dalam konteks bimbingan di Istiqomah, pernyataan Ath bukan isapan jempol belaka. Hal ini bisa dibuktikan dengan contoh peristiwa kemandirian kolektif mereka.

Dikisahkan oleh Rkm bahwa sesaat setelah para jamaah tiba di Embarkasi, para petugas kesehatan memeriksa kesehatan mereka satu per satu. Setelah Rkm dan isterinya selesai diperiksa, tiba giliran Ny. Mth (penderita Diabutus Miletus). Hasil pemeriksaan petugas menemukan kadar gula darah Mth mencapai $400 \mathrm{mg} / \mathrm{dl}$. Menurut Rkm, ketika itu Mth sangat panik. Mth paham bahwa kadar gula yang tidak normal bisa menyebabkan dirinya ditunda, atau gagal sama sekali. Menyaksikan Mth yang sedang panik itu, maka Rkm dan istrinya segera mengambil inisiatif untuk menemani Mth dan 
mengajaknya menerapkan praktik relaksasi dan terapi yang diajarkan dalam bimbingan. Setelah bebera saat, petugas pun menyuntikkan insulin kepada Mth hingga akhirnya kadar gulanya turun sampai $160 \mathrm{mg} / \mathrm{dl}$. Rkm dan istrinya baru kembali istirahat setelah masalah Mth selesai.

Dalam konteks ini perlu dipahami bahwa Rkm tidak satu regu dengan Mth. Rkm juga tidak memiliki hubungan keluarga dengan Mth. Rumah Rkm juga berbeda kecamatan dengan Mth (Ungaran Barat dan Ungaran Timur). Ketika Rkm ditanya tentang alasan menemani Mth, ia hanya menjawab bawah "turut membantu Mth adalah amanat dari bimbingan haji di Mesjid Istiqomah".

\section{Praktik Teknik-teknik Pembelajaran}

Satu aspek kemandirian dalam ibadah haji tidak bisa dibentuk hanya dengan satu teknik pembelajaran. Ada keharusan mengombinasikan antarteknik untuk mencapai suatu tujuan pembelajaran. Berikut ini adalah contoh-contoh praktiknya:

a. Teknik Pembelajaran untuk Setia Kawan

Setelah acara seremonial pembukaan usai, maka panitia melanjutkannya dengan proses awal dinamika kelompok. Kegiatan ini dilakukan dengan tujuan agar antarpeserta saling mengenal lebih dekat, sebab sebagian besar dari mereka belum saling mengenal. Tutor menggunakan metode tanya jawab. Adapun teknik pembelajarannya cenderung pada bertanya. Pertanyaan awal dilakukan oleh tutor selanjutnya ditiru oleh peserta. Setelah mereka saling bersalaman, kemudian diarahkan untuk saling bertanya tentang nama lengkap, nama panggilan, alamat, dan pekerjaan. Ada pula pertanyaan yang menjurus pada usia, keluarga dan keluhan-keluhan raganya. Orang lain bisa jadi menilai bahwa perkenalan seperti itu tabu, tetapi bagi mereka ternyata menjadi "simbol" keakraban yang dibutuhkan.

Di hari yang lain, tempat duduk mereka digeser, sehingga mereka bisa mengenal kawan yang lainnya lagi. Mereka diberi kesempatan lagi untuk saling bersalaman, berkenalan, dan saling memijak bahu kawannya. Di tengah proses dinamika itu, Msz selaku tutor memberi penguatan dengan menyampaikan sesanti yang 
disebut "6 Oj dan 1 St" (6 larangan dan satu anjuran). (1) Ojo nesu (jangan marah), (2) ojo padu (jangan bertengkar), (3) ojo ngganggu (jangan mengganggu), (4) ojo saru (jangan porno), (5) ojo sambat (jangan mengeluh), (6) ojo nyacat (jangan mencela), tetapi lakukan perilaku senang saling menolong.

Dinamika kelompok yang intensif seperti itu ternyata bukan hanya membuahkan "saling kenal", tetapi juga menumbuhkan ikatan emosional sebagai kawan yang senasib sepenaggungan.

b. Teknik Pembelajaran doa-doa

Calon jamaah haji idealnya hafal dan paham maksud dari doa-doa yang diucapkannya. Mereka disebut mandiri bila bisa mengucapkan doa secara lancar, baik dengan cara membaca atau menghafalnya. Lebih dari itu, mereka mengetahui makna intinya. Untuk maksud itu, Mfd selaku tutor menggunakan metode drill dengan teknik pembelajaran kolaboratif. Ice breaking juga digunakan untuk mengalihkan ketegangan peserta. Berikut ini adalah contoh praktik teknik pembelajaran kolaboratif supaya peserta dapat lancar, hafal, dan paham kalimat Talbiyah. Pembelajaran ini disampaikan oleh tutor berinisial Mfd.Pada awal pembelajaran, Mfd bukan hanya menggunakan tulisan talbiyah yang sudah ada dalam buku, tetapi juga menampilkannya dalam layar-LCD. Kalimat talbiyah bertuliskan Arab dan transliterasinya ditampilkan pada layar. Bentuk tulisan itu besar, sehingga jamaah mudah membacanya. Di bawah tulisan Arab dicantumkan pula terjemahannya.

Mfd menuliskan kalimat talbiyah dengan berbagai warna. Pada batas warna itulah bacaan harus berhenti. sehingga suara mereka bisa tartil dan kompak. Irama bacaan meniru ritme bertalbiyah internasional. Layar-LCD dalam pembelajaran ini berfungsi untuk mendorong minat, meningkatkan pengertian, melengkapi sumber belajar, menghemat waktu, dan membuat ingatan terhadap materi pelajaran lebih lama (H. Suprijanto, 2007: 173)

Berikut ini adalah contoh tulisan kalimat Talbiyah tersebut:

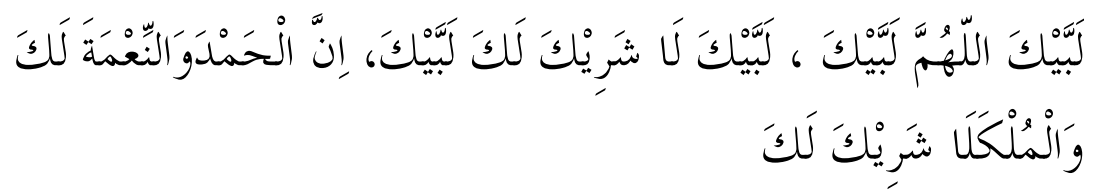


Labbaikallahumma labbaik, labbaika laa syariika laka labbaik, innal hamdawanni'matalaka walmulklaa syariikalak.

Dalam rangka ketepatan makbraj, maka Mfd menjelaskan cara membaca talbiyah dari huruf ke huruf termasuk tasydid dan sukun. "dua bibir dipertemukan dulu dan ditahan sejenak supaya bisa tepat dalam melafalkan lab baik. Mohon diperhatikan, kita mengucapkan lab baiik, bukan labaiik". Semua peserta pun menuruti anjuran Mfd itu. Mfd kemudian memberi penguatan dengan peringatan supaya mereka tidak keliru mengucapkan lafal Arabnya. "Ucapan yang salah bisa berakibat pada arti yang salah pula".

Untuk mempercepat hafalan, maka Mfd meminta peserta melafalkan talbiyah secara bergantian. Dimulai dari kelompok besar dilanjutkan dengan kelompok yang lebih kecil. Di akhir sesi, Mfd memberi kesempatan kepada salah seorang peserta untuk memimpin bacaan talbiyah.Ketika Mfd menyaksikan peserta agak tegang, maka ia mengalihkan perhatian dengan cara melafalkan talbiyah meniru lagu Sound track sinetron "Tukang Bubur Naik haji". Tulisan talbiyah pada layar pun diganti dengan warna yang berbeda, supaya mereka mudah menyesuaikan bacaannya.

Contoh:

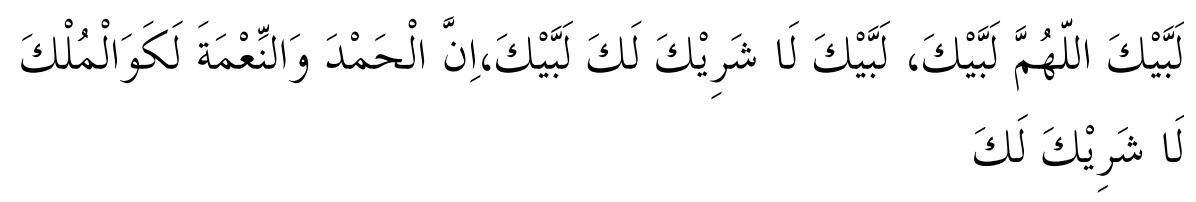

Labbaikallahumma labbaik, labbaika laa syariika laka labbaik, innal hamdawanni'matalak, walmulka laa syariikalak.

Untuk ice breaking, Hfd sesekali memancing perhatian para peserta dengan memperagakan membaca talbiyah sambil menggendong anak kecil. Seolah-olah ia ingin mengatakan, bahwa dari pada mereka menggendong cucu sambil menyanyi yang kurang baik atau diam saja, maka lebih baik menggendongnya sambil membaca talbiyah dengan irama yang merdu.

Membaca talbiyah dengan cara mengikuti lagu "sound track" tersebut ternyata lebih santai dan memudahkan peserta menghafalnya. Pada akhir pertemuan, para jamaah diberi satu lembar tulisan 
talbiyah untuk ditempel di rumahnya. Mfd menganjurkan supaya tulisan tersebut ditempel di tempat yang sering dilaluinya di rumah.

c. Teknik pembelajaran Praktik Prosesi Ibadah

Berikut ini adalah contoh praktik teknik pembelajaran untuk prosesi ibadah. Sub materi "mengenakan pakaian ihrom". Tujuan pembelajaran ini adalah supaya peserta dapat mengenakan pakaian ihrom secara tepat sesuai tuntunan syariat dan nyaman untuk dirinya.

Untuk mencapai tujuan tersebut, maka Msz selaku tutor menggunakan metode peragaan. Adapun untuk operasionalisasi metode tersebut, Msz mengolaborasikan beberapa teknik pembelajaran. Pembelajaran dibuka dengan penayangan video tata cara mengenakan pakaian ihram dan fungsinya. Msz kemudian menjelaskan kepada peserta tentang ciri-ciri pakaian ihram. "Inilah pakaian ihram yang hanya dua helai kain berwarna putih itu". Terang Msz sambil menaruh dua helai kain itu di depan jamaah yang sedang duduk bersila.

Tanpa diduga Msz mengajukan permintaan, "nyuwun tulung apakah ada dari Bapak-bapak yang kerso (bersedia) maju ke depan untuk berlatih mengenakan pakaian ihram?". Salah seorang jamaah maju mengambil kedua helai kain dan mengenakan sesuai persepsinya sendiri. Msz lalu mengatakan, "Cobi mlampah maju!!' (Coba berjalan maju). Karuan saja peserta itu nyaris tersungkur, sebab kedua kakinya kesrimpet kain ihram.

Msz lalu mengambil dua helai kain lagi dan memperagakannya. Setelah tampak sempurna, Msz mencoba berjalan cepat sambil membaca talbiyah. Peserta pun menirukan bacaan talbiyah itu. "Nah, tidak kesrimpet kan...?" tutur Msz mencoba menguatkan persepsi peserta. Ketika Msz mengenakan kain ihrom, di bagian belakang tampak ada sisa kain yang menjulur. "Pak, kenapa kain ihram itu dibiarkan ada ekornya?". tanya seorang ibu. Msz sambil tersenyum menjawab, "ini bukan ekor bu, tapi sisa lilitan kain yang bisa digunakan untuk pegangan orang lain di belakangnya". Lilitan kain ihrom itu menjadi makin kuat bila "ekor"nya ditarik.

Setelah ada satu jamaah yang mahir memakai kain ihram, Msz meminta lagi dua orang jamaah untuk maju menirukan 
temannya itu. Begitulah cara Msz menggunakan metode peragaan dengan teknik penjelasan. Penguatan juga dilakukan dengan cara memuji peserta yang bisa melakukan secara tepat.

Teknik Membuka

dan Menutup Pelajaran

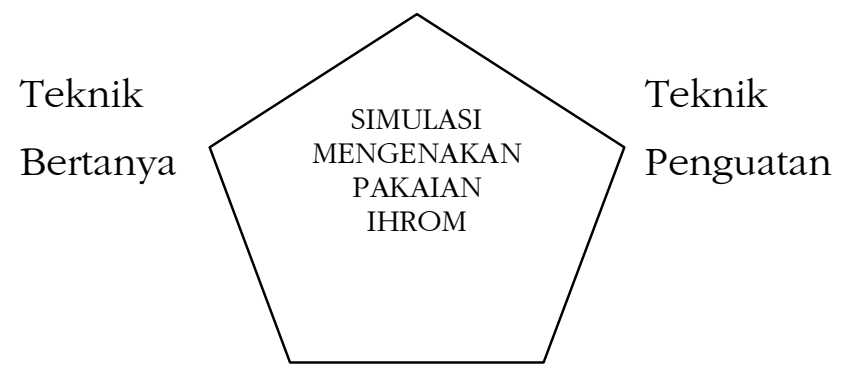

Teknik Variasi

Teknik Penjelasan

Gambar 1: Kolaborasi Teknik Pembelajaran

Ada contoh lagi tentang praktik teknik pembelajaran tawaf., Tutor materi ini masih Msz. Ia menggunakan metode ceramah. Pembelajaran dibuka dengan bertanya kepada jamaah kelompok ibu-ibu. "Bila Ibu-ibu yang hadir di ruangan ini benar-benar bisa sampai ke Makah dan mampu berputar mengelilingi ka'bah sepuluh kali, apakah sepuluh kali putaran itu akan dilakukan semua?"

Sebagian dari ibu-ibu menjawab: "ya.". Sebagian yang lain menjawab "tidak". ternyata jawaban sesama ibu masih berbeda.

Mendengar jawaban yang berbeda itu, maka Msz mencoba menjajagi jawaban dari kelompok bapak-bapak dengan melontarkan pertanyaan serupa. Ternyata jawaban mereka sama dengan kelompok ibu-ibu.

Sambil membetulkan posisi pecis coklat buatan bangka belitong, Msz menghela nafas sambil bergumam dengan logat jawanya, "emmm..., nggih....nggih......". Seolah ia ingin meyakinkan kepada para jamaah bahwa dirinya betul-betul memperhatikan jawaban mereka. 
Tanpa diduga, Msz menghampiri seorang ibu yang setiap pertemuan duduk bersila di depan. Sambil mendekat, Msz bertanya lirih kepada ibu tadi. "kalau menurut Ibu, Rasulullah melakukan tawaf mengitari ka'bah berapa kali? Si ibu tadi menjawab dengan jawaban mantap, "sak ngertose kulo, thawaf niku namung pitung ubengan" (sepengetahuan saya, tawaf itu hanya tujuh kali putaran".

Setelah si ibu tadi menyampaikan jawabannya, maka Msz berdiri sambil menguatkan pengetahuan jamaah. "Bapak dan ibu, meskipun kita kuat berputar mengitari ka'bah sepuluh kali, tetapi rasulullah hanya bertawaf tujuh kali. Oleh karena itu, cukuplah bagi kita untuk bertawaf mencontoh Rasulullah".

Msz dengan teknik penjelasannya masih berusaha memperdalam pengetahuan jamaah dengan cara bertanya. "Bagaimana bila Bapak dan Ibu ragu menghitung jumlah putaran tawaf? Ragu apakah enam putaran atau lima putaran?" Mendengar pertanyaan yang realistis itu, sebagian peserta menjawab, "lima putaran!", tetapi sebagian lagi menjawab, "enam putaran!". Karena ada keraguan jawaban dari peserta, maka Msz memberi penegasan bahwa kita memilih jumlah putaran yang lebih sedikit. Untuk menguatkan, maka Msz mengulang penegasan itu sampai tiga kali.

Teknik menjelaskan yang dilakukan oleh Msz selalu dikombinasikan dengan teknik pembelajaran yang lain. Penjelasan juga terasa hangat, sebab ada penekanan suara dan "body language" yang tepat. Ada pula istilah-istilah bahasa daerah yang digunakan, sehingga peserta merasa sejuk mendengarnya.

d. Teknik Pembelajaran untuk pemanfaatan fasilitas dan dokumen

Peralatan manasik di aula Mesjid Istiqomah itu tergolong lengkap. Ketika peserta hadir pukul 12.30, maka di bagian depan sudah siap dengan siaran live suasana Mekah dan Madinah.

Untuk memahamkan peserta pada fasilitas dan dokumen, maka Ath selaku tutor menggunakan teknik pembelajaran kolaboratif. Ath segera mengganti tayangan live tersebut dengan tayangan of line dari file laptopnya. Lokasi-lokasi penting di Madinah, Mekah, dan Armina, ditayangkan dan dijelaskan satu persatu kepada peserta.Tayangan yang disampaikan Ath sangat 
detail, sehingga kondisi obyek tampak jelas, seperti toilet, eskalator, nomer pintu masjid, tempat sandal, lorong-lorong hotel, lift, fasilitas hotel, jalan menuju mesjid, sampai bakul-bakul klitikan. Kondisi Armina juga ditayangkan secara rinci, seperti kamar mandi di Arafah, kondisi tenda, lorong-lorong Arafah, fasilitas di Musdalifah, loronglorong tenda Mina, sampai bentuk riil tugu Jamarat, dan ramburambu yang terpasang di sana.

Gambar yang dimiliki oleh Ath bukan hanya tiga dimensi, tetapi film yang sudah di potong-potong gambarnya sesuai kebutuhan. Ath menuturkan bahwa setiap tahun ada di antara para tutor yang Umrah, sehingga situasi terakhir haramain bisa diketahui. Para peserta ketika pulang haji juga ada yang memberi gambargambar kepada panitia.Penggunaan film secara live dan of line tersebut bukan hanya dapat menarik perhatian, tetapi dapat memotret kenyataan dan menimbulkan emosi (H. Suprijanto, 2007: 176). Ath berharap bahwa gambar-gambar yang ditayangkan itu menjadikan jamaah tidak merasa asing ketika sampai di haramain. Gambar yang dilihat berulang-ulang itu juga akan menambah keercayaan diri mereka.

Untuk proses penerbangan dan dokumen-dokumen perhajian, panitia menghadirkan Vra sebagai tutor khusus. Vra adalah pramugari penyerta jamaah haji di Maskapai Garuda Indonesia. Sebagai pramugari, Vra bukan hanya antusias menjelaskan aturanaturan penerbangan secara umum, tetapi juga pengalamannya membantu jamaah selama penerbangan. Vra menjelaskan tata cara penerbangan mulai mereka masuk pesawat sampai tata cara di toilet hingga mereka turun kembali. Penjelasan Vra dilengkapi pula oleh Ath dengan mempersilakan peserta melihat dan memegang dokumen-dokumen perhajian seperti paspor, buku kesehatan, gelang haji, uang real, dan dokumen lainnya. Ath menjelaskan dokumen dan fungsinya satu per satu.

Penjelasan dengan menggunakan audio-visual dan sarana motorik itu dilakukan, sebab banyak kasus-kasus kecil yang merepotkan petugas. Misalnya, jamaah haji yang sudah sepuh buang air kecil di karpet toilet, tidak di lobang closset. Ada pula jamaah yang jongkok di atas toilet. Ada orang tua yang melipat-lipat paspor dan menyimpannya di gulungan kain jarit akhirnya lupa. 
e. Teknik pembelajaran untuk Kesehatan Mandiri

Metode yang digunakan dalam pembelajaran adalah simulasi. Adapun teknik pembelajaran yang diterapkan adalah penjelasan dan variasi. Di antara para tutor, Hsn tergolong paling mahir dalam teknik terapi berpendekatan hypnoterapy.

Ia melatih peserta tentang cara-cara menerapi diri dari keluhankeluhan penyakit ringan, seperti beser, migran, dan pobia. Keluhankeluhan itu harus disembuhkan sebab sangat mungkin mengganggu kelancaran ibadah.

Hsn semula menjelaskan teknik terapi secara teoretik dengan alat bantu layar-LCD. Tahap kedua, ia meminta salah seorang jamaah yang memiliki keluhan supaya maju ke depan untuk peragaan. Setelah sesi ini berakhir, Hsn menawarkan kepada salah seorang jamaah untuk mempraktikkannya sendiri di depan. Para paserta pun memperagakan teknik yang disampaikan oleh Hsn untuk mengobati keluhannya sendiri. Menurut penuturan Nyt, Teknik pengobatan tersebut sangat bermanfaat. Selain itu, teknik-teknik pengobatan yang disampaikan oleh Hsn menjadikan jamaah haji bertambah percaya dirinya. Ia juga bisa mandiri, sebab selalu berusaha lebih dulu untuk mengobati dirinya sendiri sebelum meminta pertolongan kepada orang lain.

\section{Kesimpulan}

Kemandirian calon haji dalam konteks bimbingan di masjid istiqomah tidak selalu bersifat individual. Fenomena ini didasarkan atas fakta peserta bimbingan yang beragam dari aspek usia, kesehatan, pendidikan, profesi, dan kecakapan keagamannya. Ada peserta yang bisa mandiri secara individu dalam kecakapan membaca dan menghafal teks Arab, tetapi ia memerlukan pertolongan kawannya untuk berjalan. Ada calon haji yang mandiri untuk membawa barang-barang, tetapi ia perlu pendampingan kawannya yang terbiasa bepergian jauh. Ada calon haji yang terbiasa bepergian jauh, tetapi perlu bantuan kawannya untuk aspek keagamaan.

Kemandirian calon haji dalam konteks bimbingan di Mesjid Istiqomah ada yang bersifat kolektif. Kemandirian kolektif terbentuk karena tiga faktor, yaitu rasa setiakawan sebagai sesama kawan 
bimbingan, Kesadaran musyawarah, dan kesetiaan terhadap keputusan yang syar'i dan rasional. Tidak ada satu teknik pembelajaran yang efektif untuk satu aspek kemandirian calon haji. Untuk satu aspek kemandirian diperlukan kolaborasi teknik-teknik pembelajaran. Satu metode pembelajaran juga memerlukan kolaborasi beberapa teknis pembelajaran.

Teknik pembelajaran memerlukan dukungan dari aspek lain untuk memandirikan calon haji secara individu atau kolektif. Aspeksepek tersebut, seperti kualitas tutor, spesifikasi materi, pilihan metode, dan raw in-put peserta yang beragam. Aplikasi teknik pembelajaran bisa efektif karena ditunjang dengan pemahaman tutor terhadap kondisi peserta didik. Pemahaman dari aspek usia, profesi, pendidikan, dan kecakapan keagamaan. Dalam konteks bimbingan di Mesjid Istiqomah, mayoritas peserta adalah dewasa pertengahan dan dewasa lanjut. Profesi mereka beragam. Begitu pula pendidikannya. Oleh karena itu para tutor mengaplikasikan teknik-teknik pembelajarannya dalam kerangka pendekatan andragogi. Dengan teknik seperti itu, peserta termotivasi, sebab mereka merasa diperlakukan tepat dan terhormat.

\section{Daftar Pustaka}

Aziz, Abdul dan Kustini. 2007. Ibadah Haji dalam Sorotan Publik. Jakarta: Badan litbang dan Diklat Puslitbang Kehidupan Keagamaan Depabtemen Agama.

Basleman, Anisah, dan Syamsu Mappa. 2011. Teori Belajar Orang Dewasa. Bandung: Rosyda Karya.

Budiman Ed. 2010. Intisari Langkah-langkah pembenahan Haji. Jakarta: Direktorat Jenderal Penyelenggaraan Haji dan Umrah Kementerian Agama RI.

Budyapranata, Rm. Al., dkk.. 1997. Buku Kenangan peringatan 64 Tabun Gereja Kristus Raja Ungaran.

Departemen Agama RI. 2001. Bimbingan Manasik Haji, Umrah, dan Ziarah bagi Petugas Haji, Jakarta: Direktorat jenderal Bimbingan Masyarakat Islam dan Urusan Haji.

Departemen Agama RI, 2010. Pedoman Peragaan Manasik Haji. Jakarta: Direktorat Jenderal Bimbingan Masyarakat Islam dan 
Urusan Haji.

Departemen Agama, 2007. Pola Pembinaan jamaah Haji, Jakarta:

Dirjen penyelenggaraan Haji dan Umrah.

Departemen Agama RI. 2003. Bimbingan Manasik Haji, Jakarta:

Direktorat jenderal Bimbingan Masyarakat Islam dan Urusan Haji.

Kementerian Agama RI. 2010. Data \& Profile Penyelenggaraan Haji. Jakarta: Direktorat Jenderal Penyelenggaraan Haji dan Umrah. Kementerian Agama RI. 2011. Desain Pola Penyuluban dan Bimbingan Jemaab Haji. Jakarta: Direktorat Jenderal Penyelenggaraan Haji dan Umrah.

H. Suprijanto. 2007. Pendidikan Orang dewasa dari Teori Hingga Aplikasi. Jakarta: Bumi Aksara.

Majid, Abdul. 2013. Strategi Pembelajaran. Bandung: Remaja Rosdakarya.

Mar'at, Hj. Samsu Numiyati, Desmita psikologi Perkembangan. Bandung: Remaja Rosydakarya.

Moleong, Lexy. J. 2002. Metodologi penelitian kualitatif. Bandung: Remaja Rosyada Karya.

Sa'dullaoh, Uyoh. 2011. Pedagogik (Ilmu Mendidik). Bandung: Alfabeta.

Syaukani, Imam (Ed.). 2008. Manajemen Pelayanan Haji di Indonesia). Jakarta: Badan litbang dan Diklat Puslitbang Kehidupan Keagamaan Depabtemen Agama.

Suwarna, Dkk. 2005.Pengajaran Mikro: Pendekatan Praktis enyiapkan Pendidik Profesional.Yogyakarta: Tiara Wacana.

Thaba, Abdul Azis. 1996. Islam dan Negara dalam Politik Orde Baru. Yogyakarta. Gema Insani Press.

Tim Redaksi Wacana Intelektual. 2006., Guru dan Dosen E Sisdiknas. Tanpa Tempat Terbit. WI Press.

Tim Redaksi Sinar Grafika. 2013. Standar Nasional Pendidikan (PP No. 32 Tahun 2013 dilengkapi dengan PP No. 19 Tabun 2005). Jakarta: Sinar Grafika. 